\author{
Jan Ziótek \\ Aleksandra Kozłowska-Kukiełka
}

\title{
Księgi więzienne Zamku Lubelskiego jako źródło historyczne
}

\section{Opis dwóch ksiąg więziennych Zamku Lubelskiego z 1944 roku}

Więzienie na Zamku Lubelskim w roku 1944 znalazło się w gestii NKWD. Do 1945 roku zarząd spoczywał w rękach tej obcej formacji politycznej, po czym kierownictwo przejęło UB. Wtedy zamek zyskał rangę centralnego więzienia karno-śledczego. Trafiali tu aresztowani z wyzwolonych województw: lubelskiego, rzeszowskiego, białostockiego i częściowo z warszawskiego' ${ }^{1}$ Na parterze w części frontowej zamku, po prawej stronie, mieściły się biura administracji więziennej. Tu każdy nowo przybyły aresztant był rejestrowany wpisem do księgi więźniów. Księgi te są przedmiotem analizy i oceny jako źródło historyczne. Wzięliśmy pod uwagę zapisy w księdze pierwszej i drugiej z 1944 roku i dokonaliśmy ich opracowania. Księga druga jest powtórzeniem zapisów z księgi pierwszej i dotyczy tych samych osób, aresztowanych w 1944 roku pomiędzy lipcem a grudniem.

W tym miejscu nasuwa się pytanie, na jakiej podstawie prowadzona była rejestracja i wpis do księgi: czy na podstawie przesłuchania aresztanta czy na podstawie prokuratorskiego nakazu aresztowania. Błędy ortograficzne w nazwiskach i nazwach geograficznych mogą świadczyć, że ewidencja była sporządzana z autopsji. Fonetyczne brzmienie widoczne jest w wielu zapisach. Można też przyjąć, że błędy w księgach nie są świadectwem braku wykształcenia kancelisty, który pisał tak, jak słyszał, ale stanowią powtórzenie błędów z dokumentu aresztowania wystawionego przez organy bezpieczeństwa. O tym przekonująco świadczy kolejność rejestrów w księdze. W wielu wypadkach nie jest zachowana kolejność dat w przyjmowaniu aresztantów. W kwestii tej należy także przytoczyć rozporządzenie kierownika Resortu Bezpieczeństwa Publicznego Stanisława Radkiewicza, według którego

${ }^{1}$ Z. Kowalski, J. A. Sil, Więzienie na Zamku Lubelskim 1944-1954, Lublin 1991, s. 12; Z. Leszczyńska, Więzienie na Zamku Lubelskim w latach 1944-1954, w: Z dziejów więzienia lubelskiego, red. T. Radzik, Lublin 2007, s. 165-192. 
„przyjmowanie więźniów mogło nastąpić jedynie na mocy właściwego pisemnego nakazu przyjęcia wydanego przez władze prokuratorskie, sądowe, bezpieczeństwa publicznego, milicji obywatelskiej, administracyjne lub wojskowe"2. To przekonuje nas, że kancelista dokonywał zapisu na podstawie nakazu przyjęcia. Teza ta może być prawdziwa, jeśli weźmie się pod uwagę następujące okoliczności: kancelista czy strażnik dyżurny wpisywał do księgi osoby przybyłe w bieżącym dniu, a następnie uzupełniał rejestr danymi aresztantów, którzy doprowadzeni zostali do więzienia wcześniej. W księdze pierwszej występują jeszcze wątpliwości: różne charaktery pisma i dane osób dwukrotnie odnotowane w pierwszym i drugim rejestrze. Dane osobowe się zgadzają, ale występują błędy w zapisie nazwisk. Najczęściej dotyczy to końcówek w nazwiskach. Mogło to wynikać z treści nakazu doprowadzenia konkretnej osoby do więzienia, prezentującego podstawowe dane. Natomiast rubryki w księgach więziennych zawierają nie tylko nazwisko, rok i miejsce urodzenia oraz zamieszkania, ale dodatkowo imiona rodziców, zawód, wyznanie, narodowość, informację, kto wydał nakaz aresztowania, datę wydania i numer akt sprawy, dane o tym, skąd przybył więzień i przez kogo został doprowadzony oraz cały szereg rubryk dotyczących zwolnienia, z uwagami włącznie. Taki układ powodował, że zapisy w księgach były dokonywane w różnych okresach i przez różne osoby.

Jeszcze jedna uwaga co do dat skrajnych umieszczonych obok tytułu księgi pierwszej: obejmują one okres od 9 października do 31 grudnia 1944 roku$^{3}$, natomiast pierwsi więźniowie, co wynika z zapisu na dalszych kartach, pojawili się już 26 lipca 1944 roku. Ostatni zapis pochodzi zaś z 11 grudnia ${ }^{4}$. Końcowe trzydzieści kart tej księgi zostało wycięte i być może znajdowały się tam zapisy o więźniach $\mathrm{z}$ ostatnich dni grudnia. Niewykluczone też, że były to puste karty, co sugeruje księga druga doprowadzona do 31 grudnia $1944 \mathrm{roku}^{5}$.

Trzeba stwierdzić, że księgi więzienne niewątpliwie są źródłem dokumentowo-aktowym, ważnym dla odtwarzania martyrologii więźniów Zamku Lubelskiego. Są też źródłem oryginalnym, które przetrwało do naszych czasów w stanie dobrym. Wymiary księgi to 27 centymetrów wysokości po grzbiecie i 34 centymetry szerokości. Księga pierwsza liczy 114 kart, które nie są paginowane. Ostatnia strona nie jest do końca wypełniona, brakuje zapisu w ostatniej rubryce, co potwierdzałoby fakt, że strony wycięte były niezapisane. Blok księgi oprawiony, grzbiet i rogi wykończone szarym płótnem. W górnej części umieszczono wklejkę z wykaligrafowanym tytułem „Księga Główna Więźniów 1944”. Natomiast u dołu znajduje się naklejka z sygnaturą archiwalną Okręgowego Zarządu Zakładów Karnych w Lublinie. Poza okładką brak karty tytułowej. Pierwsza karta zapisana jest luźna, papier nieco wypłowiały, ale w dobrym stanie, tekst czytelny. Księgi mają układ tabelaryczny.

${ }^{2}$ Archiwum Państwowe w Lublinie, Centralne Więzienie w Lublinie, t. 1, s. 437.

${ }^{3}$ Archiwum Instytutu Pamięci Narodowej w Lublinie (dalej: AIPNL), Więzienie w Lublinie (dalej: WL) $1944-1954,3 / 18$.

${ }^{4}$ Tamże, k. 2 i 114.

${ }^{5}$ AIPNL, WL, sygn. 3/19. 
Zapis danych jednego więźnia w poziomym wierszu i 16 kolumnach zajmuje dwie strony. W jednej podwójnej karcie-tabeli są odręcznie zapisane dane czternastu aresztantów.

Stan księgi drugiej jest gorszy. Brakuje tylnej oprawy (okładki) i naruszone jest szycie bloku, przez to kilka kart jest luźnych. Zagięcia poszczególnych kart utrudniają czytanie tekstu. Księga druga jest nieco większa - 29 centymetrów wysokości po grzbiecie i 41 centymetrów szerokości. Zawiera zapisy danych więźniów z 1944 roku na 143 kartach. Na oprawie znajduje się tytuł „Księga Więźniów 1944 roku”, a ponadto fragment zachowanego zapisu „Księga [...] Lublin 1944/45”. Zaopatrzona jest też w sygnaturę Okręgowego Zarządu Zakładów Karnych w Lublinie. Pierwsze kilka kart nosi ślady zagięć, które czynią tekst mało czytelnym. Podobnie jak w księdze pierwszej dane osobowe więźniów zapisywane były na każdej stronie w 10 rubrykach i w 16 kolumnach. W stosunku do księgi pierwszej zapisów na jednej podwójnej stronie było o cztery mniej.

Kolumna pierwsza w rzeczonych księgach wskazuje na liczbę porządkową, pod którą więzień został wpisany. W księdze pierwszej ewidencja kończy się na numerze 1678. Bliższa analiza tej kolumny pozwala stwierdzić zawyżenie liczby więźniów o 37 osób. Wynika to z podwójnych zapisów tej samej osoby pod różnymi liczbami porządkowymi. Także niestaranność prowadzącego księgę powodowała błędy w numeracji. Na przykład po numerze 933 zarejestrowany jest więzień z numerem 944. Dodatkowy bałagan wprowadzają podwójne numery, np. po numerze 373 jest kolejny numer 354 . W wyniku takich pomyłek dwóch różnych więźniów ma ten sam numer w księdze. Prostując powyższe błędy, należy stwierdzić, że faktyczny stan zapisów w księdze pierwszej to 1641 więźniów. W księdze drugiej rejestracja kończy się na numerze $2225^{6}$. Spotyka się jednak w tej numeracji sporo błędów. Po dokładnym przeliczeniu można stwierdzić, że stan więźniów został zawyżony o 795 osób. Prowadzący księgę opuszczał numery i dwukrotnie wpisywał te same osoby. Wobec powyższego rzeczywista liczba więźniów zapisana w tej księdze wynosi 1430, w tym 996 osób zostało przepisanych z księgi pierwszej.

Kolejność zapisywania aresztantów w księdze pierwszej pozornie jest chaotyczna. Wpisy są wymieszane alfabetycznie, a daty przybycia na Zamek Lubelski są sprzeczne z kalendarzem. Pomocny w korzystaniu byłby skorowidz alfabetyczny więźniów, ale on dotyczy roku 1945 i dalszych lat. Ewidencja więźniów w księdze pierwszej zaczyna się datą 9 października 1944 roku. W tym dniu doprowadzono na zamek jedenastu aresztantów. Po ich wpisaniu kancelista uzupełniał księgę danymi osób, które zostały aresztowane i przebywały już na zamku od 26 lipca 1944 roku, a dotąd były niezarejestrowane. To spowodowało wymieszanie dat zatrzymania w październiku i listopadzie z datami wcześniejszymi (z lipca, sierpnia i września). Po każdym bieżącym zapisie znajduje się dwadzieścia lub trzydzieści zapisów danych osób aresztowanych i osadzonych wcześniej.

${ }^{6}$ Tamże, k. 143. 
Księga druga prowadzona była w dwóch układach: alfabetycznym i chronologicznym przy zachowaniu ciągłej numeracji. W części alfabetycznej wpisane są 903 osoby? $^{7}$ Brano pod uwagę pierwszą literę nazwiska aresztanta. W kilku przypadkach brak zgodności z tą zasadą. Od 91 karty zaczyna się część chronologiczna księgi drugiej, obejmująca dane 527 osób. Daty skrajne tej części księgi to 2-31 grudnia 1944 roku. Nowo przybyłych zapisywano w kolejności przybycia, podobnie jak w księdze pierwszej. Kancelista wpisywał aresztantów w kolejne dni przybycia i uzupełniał rejestr z miesięcy poprzednich od lipca do listopada. Na ogólną liczbę 1430 wpisów 996 to wpisy osób przepisane z księgi pierwszej, a tylko 434 to wpisy nowych aresztantów.

Po powyższym opisie dwóch pierwszych ksiąg więziennych Zamku Lubelskiego nasuwa się pytanie, dlaczego zostały one założone dopiero 9 października 1944 roku, skoro Sowieci już 24 lipca przejęli ten gmach i dwa dni później osadzili tu pierwszych więźniów. Można to tłumaczyć czasem potrzebnym na zorganizowanie kancelarii lub oczekiwaniem na dostarczenie odpowiednich druków. Po dokładnych oględzinach księgi pierwszej i drugiej trzeba stwierdzić, że typową księgą więzienną jest księga druga, na której wydrukowanie zapewne czekano. Posiada drukowane nagłówki kolumn i tabele wykonane w prasie drukarskiej. Natomiast księga pierwsza była przygotowana przez kancelistę z ręcznie wpisanymi nadrukami. Oczekując na właściwą księgę, stosowano zastępczą, przygotowaną w kancelarii. O tym, że druga księga jest tą, na którą czekano, świadczy jej stopka drukarska „Księga Więźniów Śledczych”. Różni się ona od pierwszej tytułami i zawartością kolumn.

Zarówno w księdze pierwszej, jak i w księdze drugiej liczba kolumn jest taka sama - szesnaście. Połowa z nich ma takie same tytuły i podobne wpisy. Dotyczą one: liczby porządkowej, nazwiska i imion aresztanta oraz jego rodziców, daty urodzenia, miejsca zamieszkania, zawodu, wyznania i uwag. Rubryki o podstawach prawnych oskarżenia mają w obu księgach różne sformułowania tytułów, ale zawierają te same informacje. Nagłówki czterech rubryk w księdze drugiej uzupełnione są o dodatkowe dane. Dotyczą one: przybycia i przerwania aresztu, władzy wydającej nakaz zatrzymania i doprowadzenia bądź zwolnienia danej osoby. Natomiast w księdze pierwszej podane są jedynie terminy oraz organy wydające nakaz aresztowania lub zwolnienia. Cechą wspólną obu ksiąg jest istnienie trzech rubryk, których tytuły nie mają równoległego odniesienia. W pierwszej księdze rubryki te dotyczą: miejsca urodzenia aresztanta, jego narodowości oraz informacji, do czyjej dyspozycji jest on oddany, natomiast w księdze drugiej znajdują się zapisy dotyczące miejsca, skąd i przez kogo dany więzień został doprowadzony, liczby dni spędzonych na Zamku Lubelskim oraz powodu przerwania aresztu. Ponieważ dane części więźniów zostały przeniesione z księgi pierwszej do drugiej, odpowiednie informacje zostały uzupełnione w rubrykach: 11., 13. i 15.

\footnotetext{
${ }^{7}$ Tamże, k. 1-91.
} 
Niedokładne prowadzenie numeracji porządkowej w obu księgach powoduje, że nie można przyjąć ostatniej liczby za rzeczywisty stan więźniów na Zamku Lubelskim. Niezbędna jest analiza kolejnych rubryk podających nazwisko i imię aresztanta, a w przypadku takich samych nazwisk - sprawdzanie dalszych danych osobowych: miejsca urodzenia, zamieszkania, zawodu, narodowości i wyznania. Trzeba zaznaczyć, że rubryki dotyczące nazwiska więźnia oraz jego rodziców były wypełniane dokładnie i bez skrótów. W zapisie nazwisk i miejscowości występują niejednokrotnie błędy ortograficzne, które w księdze drugiej zostały poprawione. Równie sumiennie prowadzona była rubryka $\mathrm{z}$ datą urodzenia więźnia - w obu księgach jest $100 \%$ zapisów. Na podstawie tych danych można określić grupy wiekowe więźniów Zamku Lubelskiego. Miejsce zamieszkania aresztanta odnotowane jest w 95\% zapisów, miejsce urodzenia w 79\%, a informacja, skąd przybył, tylko w 33\%. Te różnice wynikają z tego, że w księdze drugiej nie ma rubryki „miejsce urodzenia”, a w księdze pierwszej - „skąd dany więzień przybył”. Wpisy odnoszące się do więźniów pochodzących ze wsi lub z miasta są dokładnymi adresami z podaniem ulicy i numeru domu, gminy, powiatu i województwa. W przypadku obcokrajowców poprzestano na nazwie kraju, np. Turcja, Rosja itd. ${ }^{8} \mathrm{~W}$ nazwach miejscowości spotykamy błędy ortograficzne, co świadczy, iż prowadzący księgę nie znał najbliższej okolicy Lublina.

Trzy następne rubryki dotyczą danych osobowych więźnia i odnoszą się do zawodu, wyznania i moralności. Ostatnia informacja występuje jedynie w księdze pierwszej. Natomiast informacje o zawodzie i wyznaniu są kompletne w obu księgach. W stosunku do rolników i robotników spotyka się często tylko trzy pierwsze litery. Forma przymiotnikowa zapisu, często od dużej litery, świadczy o niskim poziomie wykształcenia kancelisty. Rubryki, w których występują informacje odnoszące się do podstawy prawnej zatrzymania, są wypełnione w $67 \%$. Najczęściej jest to krótki opis - „współpraca z Niemcami” - lub podany jest tylko artykuł z kodeksu. Drugą ważną rubryką jest informacja o władzy, która wydała nakaz aresztowania. Ona dysponowała osobą więźnia. W księdze dane te są poszerzone o datę wydania rozkazu i numeru akt sprawy. Rubryka ta wypełniona jest w $61 \%$, jeśli chodzi o datę wydania nakazu aresztowania, i w 18\%, jeśli chodzi o datę zwolnienia. Nazwa organów władzy w tym wypadku pisana jest skrótami, np. „WUBP” lub „Prok. N. Gar. Lub.”. Rubryka w księdze drugiej, przeznaczona na wpisanie liczby dni pobytu aresztanta na Zamku Lubelskim, jest pusta. Można natomiast odtworzyć czas pobytu więźnia na podstawie dwóch innych rubryk: „data przybycia” i „dzień przerwania aresztu”. Zapisy te są dokładne: dzień, miesiąc i rok, niekiedy godzina przybycia lub zwolnienia. Powód zwolnienia w księdze pierwszej opisywano w rubryce „uwagi”. W księdze drugiej poświęcona była tym zapisom kolumna podzielona na dwie części mniejsze wzdłuż linii pionowych. W nagłówkach figurowały zapisy: ,,zwolniony”, ,,rozpoczęcie odbywania kary”, ,śmierć naturalna” lub „,samobójcza”, ,ucieczka” i ,,przeniesienie do innego więzienia". Kancelista stawiał jedynie pionowe kreski w odpowiednich

${ }^{8}$ AIPNL, WL sygn. 3/18, k. 18, 29. 
rubrykach. Ostatnia rubryka „uwagi” wypełniona jest w 93\%. Figurują tu informacje o dalszych losach więźnia, numery, pod którymi należy szukać danej osoby w innej księdze, lub też wpisana jest władza, która wydała rozkaz zwolnienia.

Na zakończenie tej części zestawienia danych w „Księgach więziennych Zamku Lubelskiego w drugiej połowie 1944 roku" zamieszczamy wykaz rubryk, ilość zapisów, brak danych i procent wypełnionych rubryk:

\begin{tabular}{|c|c|c|c|}
\hline Nazwa rubryki & Ilość danych & Brak danych & $\mathbf{\%}$ \\
\hline Nazwisko i imię więźnia śledczego & 2074 & 1 & 100 \\
\hline Imiona rodziców & 2074 & 1 & 100 \\
\hline Data urodzenia & 2074 & 1 & 100 \\
\hline Miejsce urodzenia & 1639 & 436 & 79 \\
\hline Miejsce zamieszkania & 1985 & 90 & 96 \\
\hline Zawód & 2062 & 13 & 99 \\
\hline Narodowość & 1579 & 496 & 76 \\
\hline Wyznanie & 1987 & 88 & 96 \\
\hline Oskarżony z art. & 1391 & 684 & 67 \\
\hline Władza wydająca rozkaz o przyjęciu & 2003 & 72 & 96 \\
\hline Data wydania rozkazu o przyjęciu & 1267 & 808 & 61 \\
\hline Do czyjej dyspozycji & 455 & 1620 & 22 \\
\hline Data przybycia & 2069 & 6 & 99 \\
\hline Liczba dni spędzonych w areszcie & 702 & 1373 & 33 \\
\hline Uwagi & 1929 & 1056 & 49 \\
\hline Wkąd przybył więzień i przez kogo doprowadzony & 1906 & 169 & 92 \\
\hline Władza wydająca rozkaz zwolnienia & 579 & 1696 & 18 \\
\hline Data wydania rozkazu zwolnienia & 1624 & 451 & 78 \\
\hline Data zwolnienia & 2075 & 03 \\
\hline Pow przerwania aresztu & 146 & 93 \\
\hline
\end{tabular}

\section{Stan osobowy więźniów Zamku Lubelskiego w 1944 roku na podstawie dwóch pierwszych ksiąg}

Na podstawie opisanych wcześniej dwóch pierwszych ksiąg więźniów Zamku Lubelskiego przedstawimy faktyczny stan zaludnienia osławionego zamku. Śledząc liczby porządkowe i zamieszczone pod nimi nazwiska i imiona aresztowanych, można 
z grubsza określić stan osobowy zakładu karnego. Z góry zakładamy, że nie będą to liczby dokładne, ponieważ oddział IV był wyłączony ze struktury więzienia. Podlegał on bezpośrednio WUBP, a aresztanci tu przebywający nie byli rejestrowani w „Księgach głównych więźniów śledczych”. Ustalenie faktycznej liczby więźniów politycznych na Zamku Lubelskim w roku 1944 nie jest łatwe. Alina Gałan i Zygmunt Mańkowski podają liczbę 2044 więźniów przebywających na zamku w ostatnich miesiącach 1944 roku $^{10}$. Wcześniej Stanisław Radkiewicz, kierownik Rady Bezpieczeństwa Publicznego, na posiedzeniu PKWN w dniu 4 października 1944 roku wymienił okrągłą liczbę 3 tys. aresztowanych przez organa bezpieczeństwa w okresie 2 miesięcy, tj. w sierpniu i we wrześniu. Nie wszyscy jednak musieli trafić do więzienia na zamku - tak jak ci, o których mówił pół roku później na posiedzeniu Rady Jedności Narodowej gen. Leopold Okulicki. Stwierdził on, że od lipca do grudnia 1944 roku zostało aresztowanych ok. 30 tys. żołnierzy Armii Krajowej ${ }^{11}$. Analizując księgi główne Zamku Lubelskiego, możemy określić, że od lipca do grudnia 1944 roku ogólna liczba aresztantów nie przekraczała 2075 osób, w tym 1712 mężczyzn i 363 kobiety.

Pod względem wiekowym i z uwagi na podstawę oskarżenia więźniowie w celach byli wymieszani. W jednej sali przebywali zarówno młodzi ludzie, jak i starsi, więźniowie polityczni i kryminalni, żołnierze Polski Podziemnej i funkcjonariusze SS. Była to działalność celowa, ponieważ więźniowie kryminalni mieli za zadanie znęcać się fizyczne i moralnie nad współtowarzyszami, będącymi więźniami politycznymi. Analizując rubrykę „,data urodzenia”, można ustalić kilka grup wiekowych więźniów Zamku Lubelskiego w 1944 roku. Poniższa tabela obrazuje ten stan:

\begin{tabular}{|c|c|c|}
\hline Grupa wiekowa & Liczba więźniów & \% \\
\hline Do lat 18 & 253 & 7,4 \\
\hline $19-25$ & 561 & 27,0 \\
\hline $26-35$ & 516 & 24,8 \\
\hline $36-50$ & 612 & 29,5 \\
\hline Powyżej 50 lat & 234 & 11,3 \\
\hline Razem & 2075 & 100,0 \\
\hline
\end{tabular}

Na podstawie analizy rubryki „data przybycia” aresztanta wynika, że pierwsze osoby zostały doprowadzone już 26 lipca 1944 roku, czyli cztery dni po zajęciu Lublina przez wojska sowieckie i polskie i ogłoszeniu manifestu PKWN. Liczby aresztowanych z każdym miesiącem wzrastały, co ilustruje poniższa tabela:

\footnotetext{
${ }^{9}$ H. Pająk, S. Żochowski, Rządy zbirów 1940-1990, Lublin 1996, s. 65.

${ }_{10}$ Więźniowie polityczni na Zamku Lubelskim 1944-1954, red. A. Gałan, Z. Mańkowski, Lublin 1996, s. 98.

${ }^{11}$ D. Baliszewski, A. K. Kunert, Ilustrowany przewodnik po Polsce stalinowskiej 1944-1956, Warszawa 1999, s. 100.
} 


\begin{tabular}{|c|c|}
\hline Miesiąc & Liczba osób przybyłych do więzienia na zamku \\
\hline Lipiec & 17 \\
\hline Sierpień & 56 \\
\hline Wrzesień & 94 \\
\hline Październik & 600 \\
\hline Listopad & 796 \\
\hline Grudzień & 516 \\
\hline Brak danych & 6 \\
\hline Razem & 2075 \\
\hline
\end{tabular}

W przypadku sześciu osób brak jest daty przybycia. Nasuwa się pytanie, skąd tak wielki skok aresztowań między pierwszymi trzema miesiącami a trzema ostatnimi. Dariusz Baliszewski i Andrzej K. Kunert tłumaczą ów przełom w liczbie aresztowań zmianą stosunku komunistów do Polski Walczącej w czasie okupacji niemieckiej i po wkroczeniu Sowietów na ziemie polskie. Bezpośredniego powodu zmiany postawy komunistów upatrują w wizycie przedstawicieli KRN i PKWN w Moskwie w dniach 28 września - 3 października 1944 roku. Podczas rozmów Stalin skrytykował polskich komunistów „za miękkość, za rozlazłość”, za to, że wobec wroga politycznego „nie umieją wystąpić śmiało”"12. Bolesław Bierut, relacjonując to spotkanie na posiedzeniu KC PPR w Lublinie, krytykował prace resortu bezpieczeństwa. Domagał się, by nie tylko likwidować przeciwników politycznych, ale także prowadzić działalność profilaktyczną. Unieszkodliwiać tych, którzy przeciwstawiają się programowi PKWN. Ze stanowiskiem Bieruta zgodził się Radkiewicz, który stwierdził, że „początkowo akowców nie aresztowaliśmy, rozbrajaliśmy ich i odsyłaliśmy do wojska”. Dalej podkreślił: „Chciałbym, żeby nasza dotychczasowa polityka liberalna uległa zmianie i ustąpiła miejsca większej czujności”’13.

Po tych naradach w październiku zorganizowana została dywizja NKWD w składzie 6 pułków, samodzielnego batalionu i jednostek pomocniczych w sile 10 282 żołnierzy, pod dowództwem gen. mjr. Borysa Pawłowicza Gerebrafowa. Dywizja rozpoczęła działalność na Lubelszczyźnie 14 października 1944 roku. W tym czasie więzienie na Zamku Lubelskim było największe na terenie Polski, dlatego kierowano tu aresztantów z różnych części kraju, przebywających w aresztach służb bezpieczeństwa. Zostało to wyraźnie odnotowane w księdze więziennej, w rubryce „skąd przybył więzień” i „miejsce zamieszkania”. Na tej podstawie można sporządzić wykaz obrazujący terytorialne pochodzenie więźniów Zamku Lubelskiego w 1944 roku:

\footnotetext{
12 Tamże, s. 111.

13 Tamże, s. 100.
} 
Księgi więzienne Zamku Lubelskiego jako źródło historyczne...

\begin{tabular}{|c|c|}
\hline Województwo & Liczba więźniów \\
\hline Białostockie & 5 \\
\hline Bydgoskie & 3 \\
\hline Gdańskie & 2 \\
\hline Katowickie & 6 \\
\hline Kieleckie & 29 \\
\hline Krakowskie & 7 \\
\hline Lubelskie & 1728 \\
\hline Lódzkie & 1 \\
\hline Poznańskie & 6 \\
\hline Rzeszowskie & 46 \\
\hline Warszawskie & 117 \\
\hline Wrocławskie & 2 \\
\hline Nieokreślone & 123 \\
\hline
\end{tabular}

Jak wynika z powyższego zestawienia, aresztanci na Zamku Lubelskim pochodzili z 12 województw. Najliczniejszą grupę stanowili więźniowie z województwa lubelskiego. Musimy też pamiętać, że w 1944 roku na Lubelszczyźnie przebywali osiedleńcy wypędzeni przez Niemców z województw zachodnich i północnych Polski. Ponadto 31 osób zarejestrowanych w księdze więziennej Zamku Lubelskiego podało miejsce zamieszkania poza granicami Polski:

\begin{tabular}{|c|c|}
\hline Miejsce zamieszkania & Liczba więźniów \\
\hline Drohobycz & 2 \\
\hline Janów Miński & 1 \\
\hline Lwów & 1 \\
\hline Nowogard Wołyński & 1 \\
\hline Odessa & 1 \\
\hline Riazań & 2 \\
\hline Trembowla & 1 \\
\hline Troki & 2 \\
\hline Wilno & 2 \\
\hline Wołkowysk & 1 \\
\hline Wołyń & 1 \\
\hline Jugosławia & 1 \\
\hline Niemcy (Frankfurt) & \\
\hline & \\
\hline
\end{tabular}


Część wymienionych w tabeli terenów należała przed 1939 rokiem do Polski, a na podstawie tymczasowego ustalenia granic w lipcu 1944 roku, ostatecznie zaś na mocy układu z 16 sierpnia 1945 roku, weszła w skład ZSRR. Terytorium polskie po II wojnie światowej stało się pod względem narodowościowym jednolite, a mniejszości stanowiły jedynie $2 \%$ ogólnej liczby mieszkańców.

Zróżnicowanie narodowościowe więźniów Zamku Lubelskiego w 1944 roku, odnotowane w księgach, obrazuje poniższa tabela:

\begin{tabular}{|c|c|}
\hline Narodowość & Liczba więźniów \\
\hline Białoruska & 3 \\
\hline Jugosłowiańska & 1 \\
\hline Niemiecka & 13 \\
\hline Ormiańska & 1 \\
\hline Polska & 1510 \\
\hline Rosyjska & 13 \\
\hline Turecka & 1 \\
\hline Ukraińska & 27 \\
\hline Żydowska & 6 \\
\hline Brak danych & 496 \\
\hline
\end{tabular}

Największą grupę stanowili Polacy, pozostałe nacje w granicach od 1 do 27 osób. Stosunkowo duża grupa nie posiada wypełnionej rubryki odnoszącej się do narodowości. Trzeba zauważyć, że przynależność narodowa więźniów nie zawsze była równoznaczna z miejscem urodzenia. Ponadto dane dotyczące tego zagadnienia otrzymujemy jedynie na podstawie księgi pierwszej, ponieważ w księdze drugiej nie ma takiej rubryki. Przyjrzyjmy się zatem klasyfikacji według miejsca urodzenia więźniów osadzonych na Zamku Lubelskim w 1944 roku:

\begin{tabular}{|c|c|}
\hline Państwo & Liczba więźniów \\
\hline Czechy & 1 \\
\hline Francja & 2 \\
\hline Jugosławia & 1 \\
\hline Lotwa & 1 \\
\hline Nadrenia & 2 \\
\hline Niemcy & 17 \\
\hline Polska & 1585 \\
\hline Rosja & 23 \\
\hline
\end{tabular}


Księgi więzienne Zamku Lubelskiego jako źródło historyczne...

\begin{tabular}{|c|c|}
\hline Państwo & Liczba więźniów \\
\hline Rumunia & 1 \\
\hline USA & 4 \\
\hline Turcja & 1 \\
\hline Ukraina & 2 \\
\hline Brak danych & 436 \\
\hline
\end{tabular}

Pisownia nazw państw w tabeli jest zgodna z zapisem w księdze więziennej ${ }^{14}$.

Analizując rubrykę ,wyznanie”, można podzielić więźniów Zamku Lubelskiego jak w tabeli poniżej:

\begin{tabular}{|c|c|}
\hline Wyznanie & Liczba więźniów \\
\hline Bezwyznaniowy & 24 \\
\hline Ewangelickie & 19 \\
\hline Ewangelicko-augsburskie & 1 \\
\hline Mahometańskie & 1 \\
\hline Mojżeszowe & 8 \\
\hline Prawosławne & 1876 \\
\hline Rzymskokatolickie w obrządku łacińskim & 10 \\
\hline Greckokatolickie & 88 \\
\hline Brak danych &
\end{tabular}

Największą grupę stanowili więźniowie wyznania rzymskokatolickiego obrządku łacińskiego: 90\% ogólnej liczby. Z pozostałych wyznań tylko prawosławne przekroczyło $2 \%$, pozostałe mieściły się w granicach $1 \%$.

Rubryka dotycząca zawodu wypełniona jest w księdze w 99\% i stanowi doskonały materiał do ustalenia, jakie grupy zawodowe przebywały w więzieniu na Zamku Lubelskim.

\begin{tabular}{|c|c|}
\hline Resort & Liczba więźniów \\
\hline Rolnictwo & 601 \\
\hline Górnictwo i przemysł & 597 \\
\hline Służba publiczna & 258 \\
\hline Szkolnictwo i kultura & 158 \\
\hline Komunikacja i transport & 117 \\
\hline
\end{tabular}

${ }^{14}$ AIPNL, rkps, sygn. 3/18, k. 29, 44, 36, 43 i in. 


\begin{tabular}{|c|c|}
\hline Resort & Liczba więźniów \\
\hline Handel & 87 \\
\hline Utrzymujący się bez pracy & 84 \\
\hline Służba domowa & 40 \\
\hline Ogrodnictwo, leśnictwo, rybołówstwo & 33 \\
\hline Lecznictwo, utrzymanie czystości & 29 \\
\hline Zawód niewiadomy & 58 \\
\hline Brak danych & 13 \\
\hline
\end{tabular}

Ponieważ w zapisach podział według zawodów jest mało precyzyjny, przyjęto w powyższym zestawieniu profesje zdobyte przed wybuchem II wojny światowej. Podział, jaki został zastosowany, pochodzi z rocznika statystycznego z 1939 roku. Największe grupy stanowili więźniowie, których źródłem utrzymania było rolnictwo, górnictwo i przemysł. Musimy pamiętać, że wśród rolników byli agronomowie, inżynierowie rolnictwa oraz zarządcy i administratorzy majątków. Aresztowania na wsiach następowały często, gdy NKWD i UB przeczesywały wsie w poszukiwaniu ukrywających się żołnierzy Armii Krajowej. Rolnicy mieli rzekomo udzielać pomocy członkom zbrojnego podziemia i ukrywać broń ${ }^{15}$. W wielu przypadkach stosowano odpowiedzialność zbiorową całych rodzin, czego dowodem są kolejne nazwiska wpisane do księgi więziennej (czasem zapisanych jest nawet pięć osób o tym samym nazwisku).

Równie liczną grupę stanowili ludzie związani z przemysłem: górnicy, hutnicy, rzemieślnicy, usługowcy, zecerzy, ceramicy oraz uczniowie takich zawodów, jak: piekarz, szewc, masarz, ślusarz czy kowal. Zaliczono do tej grupy też kobiety: trykociarki, krawcowe, fryzjerki, kelnerki. Trzecia liczna grupa Zamku Lubelskiego to przedstawiciele służby publicznej, przede wszystkim pracownicy Delegatury Rządu RP w Londynie. Po przystąpieniu do organizowania administracji lokalnej NKWD aresztowało na terenie Lubelszczyzny większość delegatur wojewódzkich, powiatowych, burmistrzów i wójtów ${ }^{16}$. Na zamku osadzono m.in. wicestarostów, sekretarzy gminnych i biuralistów, a spośród kobiet: sekretarki, pomocnice biurowe i dozorczynie. Zagrożeni aresztowaniem byli także przedwojenni sędziowie i adwokaci. W grudniu 1944 roku Stanisław Radkiewicz wydał zarządzenie dla komendantów MO i WUBP w sprawie postępowania w czasie aresztowania sędziów. Przed przystąpieniem do czynności zatrzymania sędziego chronionego immunitetem należało się zwrócić do RBP o wydanie specjalnego zezwolenia ${ }^{17}$. Na Zamku Lubelskim przetrzymywano asesorów i sekretarzy sądowych, sędziów, magistrów

\footnotetext{
${ }^{15}$ Z. Muszyński, Lublin. Narodziny terroru. „Relacje”, 1989 nr 29-30.

${ }^{16}$ S. Jadczak, Powojenny dramat Polaków, „Kurier Lubelski”, 1990, nr 215.

${ }^{17}$ Więźniowie polityczni na Zamku Lubelskim, s. 125.
} 
prawa, aplikantów adwokackich i adwokatów. Jednym z uwięzionych na zamku był Mieczysław Tudrej, starszy asystent w katedrze Prawa Karnego KUL. Do grupy służby publicznej zaliczeni zostali policjanci granatowi (oskarżani o współpracę z Niemcami) oraz żołnierze Wojska Polskiego: oficerowie, podoficerowie, kapelani i szeregowi. Pozostałe grupy zawodowe nie przekraczały $10 \%$ stanu więźniów Zamku Lubelskiego w 1944 roku. Ze środowiska szkolnictwa i kultury więziono: uczniów, studentów, nauczycieli, profesorów, artystów malarzy, śpiewaków i cyrkowców. Wśród straconych na zamku była Zofia Pelczarska, nauczycielka i kierowniczka szkoły powszechnej nr $12 \mathrm{w}$ Lublinie $^{18}$, Marian Sikora, porucznik AK, i Stefan Rodak, żołnierz BCh, student KUL.

W grupie więźniów zawodowo związanych z komunikacją i transportem byli pracownicy PKP i poczty, a także piloci, szoferzy, drogowcy, dorożkarze i furmani. Do grupy związanej z handlem zaliczono: kupców, handlowców, spółdzielców, sekwestratorów, prokurentów, ekonomistów i kasjerów. Wśród kobiet były ekspedientki i kasjerki. Natomiast do grupy utrzymującej się bez pracy weszli: emeryci, nieletni będący pod opieką rodziców oraz kobiety na utrzymaniu mężów. Do służby domowej zaliczano kobiety, które były pomocnicami lub gospodyniami domowymi. Wśród więźniów, przy których nazwiskach w księdze istnieje adnotacja „bez zawodu”, znajdowały się kobiety, przy nazwiskach których wpisano „wdowa”. Jak widać z powyższego przeglądu, na Zamku Lubelskim w 1944 roku więzieni byli ludzie różnych zawodów i o różnym wykształceniu.

W księdze więziennej, bezpośrednio po odnotowaniu danych osobowych więźnia, kancelista zapisywał podstawę prawną oskarżenia. Były to numery artykułów $\mathrm{z}$ odniesieniem do dekretu lub kodeksu. Zdarzają się też informacje opisowe, np. „współpraca z Niemcami”. Jednak w tej rubryce stosunkowo często brak wypełnienia, nie ma go aż przy 684 nazwiskach osób aresztowanych. Największa grupa więźniów sądzona była na podstawie dekretu „O ochronie państwa” ${ }^{\text {. }}$. Dekret ten z naruszeniem zasady ius retro non agit był stosowany od 15 sierpnia 1944 roku, chociaż wydany został dopiero 30 października, a ogłoszony 3 listopada 1944 roku. Wynika to $\mathrm{z}$ wielu zapisów w księdze, prawdopodobnie wypełnionej po 3 listopada. W artykułach zawarto przestępstwa polityczne, administracyjne, gospodarcze i przeciwko porządkowi publicznemu. Każdy z artykułów groził wieloletnim więzieniem do kary śmierci włącznie. Dekret ten określany jest jako „hańba polskiego wymiaru sprawiedliwości" ${ }^{20}$. Na podstawie tego dekretu oskarżono i skazano 631 więźniów Zamku Lubelskiego. Jak wynika z zapisu w księdze więziennej aż 535 osób oskarżono $\mathrm{z}$ artykułów, które dotyczyły członków organizacji konspiracyjnych i partii politycznych związanych z emigracyjnym rządem polskim, rzekomo mającym na celu „obalenie demokratycznego ustroju”. W księdze więźniów Zamku Lubelskiego

${ }^{18}$ D. Baliszewski, A. K. Kunert, dz. cyt., s. 163.

${ }^{19}$ Dziennik Ustaw RP 1944, nr 10, poz. 50.

${ }^{20}$ T. Żenczykowski, Polska Lubelska 1944, Warszawa 1990, s. 85; M. Turlejska, Te pokolenia żatobami czarne. Skazani na śmierć i ich sędziowie, Warszawa 1990, s. 43. 
odnotowane są numery artykułu dekretu oraz nazwa organizacji lub stwierdzenie „działalność antypaństwowa”. Wśród adnotacji dotyczących organizacji znajdujemy informacje o 519 członkach Armii Krajowej, trzech - Narodowych Sił Zbrojnych, trzech - Batalionów Chłopskich, a także o jednym żołnierzu Związku Walki Zbrojnej. Przytoczone liczby nie odzwierciedlają w pełni rzeczywistości, bo - śledząc nazwiska - stwierdzamy kilkadziesiąt pozbawionych adnotacji nazwisk osób należących do AK i innych organizacji niepodległościowych.

Na rozkaz Stalina PKWN w sierpniu wydał dekret „O rozwiązaniu tajnych organizacji wojskowych na terenach wyzwolonych"²1. Duża część wyżej wymienionych organizacji konspiracyjnych nie miała prawa bytu, a jej żołnierzy aresztowały NKWD i UB i osadzały na Zamku Lubelskim. Upominanie się o wolność i niepodległość państwa uznane było przez Sowietów za zbrodnię i karano je śmiercią ${ }^{22}$. Za groźnych dla państwa uznawano, zgodnie z artykułem 4. dekretu, „wyrabiających oraz przechowujących broń i amunicję”, a także „osoby sprowadzające niebezpieczeństwo w komunikacji lub wiedzące o nim”, które „nie zapobiegły wypadkowi”. W przypadku tych osób w księdze więziennej zapisywano numer artykułu bądź zaznaczano „broń” lub „nielegalne posiadanie broni”, lub „przetrzymywanie amunicji”. Zarzut nielegalnego posiadania broni odnotowano w księdze w 36 wypadkach. Przestępstwem było „udaremnianie lub utrudnianie wprowadzania reformy rolnej” lub „nieoddawanie kontyngentów”. Nazwiska takich osób figurują w księdze pod zapisem „reforma rolna”, „sabotaż reformy rolnej” lub „,agitacja przeciw zdawaniu kontyngentów" - były to artykuły 1. i 10. dekretu. Przestępstwa tego dopuściły się w opinii NKWD 32 osoby, w większości rolnicy. Obowiązek dostarczania zboża, ziemniaków, mięsa, mleka i siana został wprowadzony na Lubelszczyźnie w lipcu 1944 roku. Za uchylanie się od niego rolnik zostawał okrzyknięty sabotażystą i podlegał karze więzienia lub śmierci. Wystarczającym powodem, by znaleźć się na Zamku Lubelskim było posiadanie radia. W księdze więziennej przy pięciu nazwiskach widnieje adnotacja o nielegalnym posiadaniu radia.

Liczną grupę na Zamku Lubelskim w 1944 roku stanowili więźniowie sądzeni na podstawie Kodeksu Karnego Wojska Polskiego. W księdze więziennej figurują 532 odnotowania skazanych z KKWP. Najwięcej, bo 307 osób, to osoby skazane z artykułów 100., 101. i 103., „współpracownicy z Niemcami”, „służący w byłej armii niemieckiej”. Te argumenty sądy wojskowe stosowały wobec żołnierzy Armii Krajowej. Bardzo często ludzi tych skazywano pod pretekstem współpracy z okupantem lub „za faszyzm”. Przykładem może być Antoni Lisewski - żołnierz AK, oskarżony o współpracę z Niemcami i zamordowany w grudniu $1944 \mathrm{roku}^{23}$. Na

${ }^{21}$ M. Turlejska, Z walki przeciwko zbrojnemu podziemiu 1944-1947, Warszawa 1966, s. 26.

${ }^{22}$ Z. Leszczyńska, Ginę za to, co najgłębiej człowiek ukochać może. Skazani na karę śmierci przez sady wojskowe na Zamku Lubelskim (1944-1945), t. 1, Lublin 1998; t. 2: Członkowie organizacji niepodległościowych na Lubelszczyźnie skazani na karę śmierci przez sądy wojskowe (1944-1955), Lublin 2004; taż, Kobiety Lubelszczyzny represjonowane w latach 1944-1956, t. 1, Lublin 2002.

${ }^{23}$ Z. Muszyński, Gdzie jest grób Antoniego Lisewskiego, „Prawo i Życie”, 1989, nr 25, s. 1. 
podstawie KKWP sądzeni byli dezerterzy z Ludowego Wojska Polskiego. Na Zamku Lubelskim odnotowano 53 osoby skazane z tego oskarżenia. Po kilka osób osądzono za przekupstwo, fałszywe zeznania, fałszowanie dokumentów oraz przestępstwa urzędnicze, przekraczanie kompetencji, działanie na szkodę państwa, przyjmowanie łapówek itp.

W więzieniu na Zamku Lubelskim w 1944 roku przebywało 258 ludzi oskarżonych z dekretu sierpniowego. Stosowano go wobec ,faszystowsko-hitlerowskich zbrodniarzy winnych zabójstw i znęcania się nad ludnością cywilną i jeńcami oraz wobec zdrajców Narodu Polskiego"24. Dziewięć artykułów tego dekretu przewidywało karę śmierci za przestępstwa wymienione w samym tytule owego aktu prawnego. Często sądy wojskowe wykorzystywały ten dekret wobec żołnierzy AK i całego niepodległościowego podziemia. W księdze więziennej w rubryce „oskarżony” aż 239 osobom sądzonym z powyższego dekretu zapisano ,volksdeutsche”, a tylko sześciu „Niemiec”. Dekret sierpniowy stosowano także wobec tzw. policjantów granatowych. Zarzucano im współpracę z okupantem niemieckim, udział w policji kryminalnej i zwalczanie nurtu lewicowego. Wśród więzionych na Zamku Lubelskim odnotowano 14 policjantów. Spośród sądzonych z dekretu sierpniowego w księgach przy 65 więźniach zapisano literę „S”, w odróżnieniu od oskarżonych przez prokuraturę.

Na podstawie ksiąg więziennych Zamku Lubelskiego można ustalić podstawy prawne oskarżeń:

\begin{tabular}{|c|c|}
\hline Podstawa prawna & Liczba oskarżonych \\
\hline Dekret „O ochronie państwa” & 644 \\
\hline KKWP & 478 \\
\hline Dekret sierpniowy & 337 \\
\hline Mały kodeks karny & 3 \\
\hline Razem & 1462 \\
\hline
\end{tabular}

Przytoczone liczby nie są stanem faktycznym, dla pozostałych brak adnotacji w odpowiedniej rubryce w księdze.

Warto się przyjrzeć rubrykom w księgach więziennych Zamku Lubelskiego z roku 1944, a dotyczących ,zwalniania z aresztu”. W księdze pierwszej przerwanie aresztu odnotowywano w rubryce „Uwagi”, natomiast w drugiej (drukowanej) była kolumna, w której wyszczególniono: zwolnienie, rozpoczęcie odbywania kary, śmierć naturalna lub samobójcza, ucieczka, przeniesienie do innego więzienia lub zakładu. Kancelista wstawiał jedynie kreski w rubryce z odpowiednim nazwiskiem. Jednak urzędnik prowadzący rejestr często uzupełniał zapisy według własnych

${ }^{24}$ Dziennik Ustaw RP 1944, nr 4, poz. 16. 
kwalifikacji. Dlatego rubryka o zwolnieniu nie zawsze równała się odzyskaniu wolności. Znajdujemy dopiski: „Zwolniony RKU” (Rejonowa Komenda Uzupełnień), „zwolniony d-tj” (deportacja). Zamek Lubelski był więzieniem karno-śledczym, osadzeni więźniowie przebywali tu do rozprawy, a następnie byli odsyłani do innych zakładów karnych. Przy wielu zapisach jest podane miejsce, np. „obóz w Krzesimowie” lub „więzienie w Siedlcach”, a obok dopiski: „przeniesiony”, ,zabrany” do UB, RKU, WP, szpitala itd. Obok wyżej wymienionych mamy informacje dotyczące dat: dzień, miesiąc, rok i nawet godzina przerwania aresztu. Ostatnia informacja nie zawsze była zapisywana. Tak jak nazwa władzy, która wydała nakaz zwolnienia i numer akt sprawy.

Wśród tytułów sześciu rubryk z wyszczególnionymi powodami przerwania aresztu nie było „wykonania wyroku śmierci”. Poniższe zestawienie przedstawia powody przerwania aresztu wpisane do księgi więziennej Zamku Lubelskiego ${ }^{25}$ :

\begin{tabular}{|c|c|}
\hline Powód przerwania aresztu & Liczba więźniów \\
\hline Zwolniony & 704 \\
\hline Przeniesiony do obozu pracy & 415 \\
\hline Przeniesiony bez podania punktu docelowego & 206 \\
\hline Zwolniony & 205 \\
\hline Wcielony do WP & 128 \\
\hline Ubył & 65 \\
\hline Przeniesiony do więzienia & 57 \\
\hline Przekazany do UB & 56 \\
\hline Zmarł & 31 \\
\hline Ucieczka & 16 \\
\hline Wyrok śmierci & 14 \\
\hline Przeniesiony do szpitala & 5 \\
\hline Powiesił się & 2 \\
\hline Przekazany do Zarządu Informacji WP & 2 \\
\hline Brak informacji & 169 \\
\hline Razem & 2075 \\
\hline
\end{tabular}

Wyroki śmierci opiniowali: ppłk Konstanty Krukowski lub gen. Aleksander Tarnowski. Zatwierdzali: naczelny dowódca WP gen. Michał Rola-Żymierski, a podczas jego nieobecności gen. Karol Świerczewski, gen. Zygmunt Berling, gen. Leon

${ }^{25}$ AIPNL, sygn. 3/18 i 3/19. 
Bukojewski i płk Włodzimierz Radziwanowicz. Prawo ułaskawienia i zamiany wyroku śmierci na dożywotnie więzienie należało do Bolesława Bieruta, gen. Michała Roli-Żymierskiego i gen. Karola Świerczewskiego. Najczęściej jednak pisali „odmawiam” lub „nie wyrażam zgody na ułaskawienie"26.

Z zapisów w księgach więziennych Zamku Lubelskiego wynika, że od lipca do grudnia straciło tu życie 47 osób, w tym przy nazwiskach 31 osób zapisano, że zmarły śmiercią naturalną, 2 powiesiły się, a na 14 dokonano egzekucji. Wśród 14 egzekucji były dwie egzekucje kobiet. Ofiary były rozstrzeliwane lub wieszane. Przy nazwiskach siedmiu osób nie jest podany rodzaj śmierci, a jedynie informacja „wykonano wyrok śmierci”. Nie przy wszystkich nazwiskach skazanych i straconych kancelista fakt ten odnotował. Wiadomo, że wśród zamordowanych na Zamku Lubelskim w 1944 roku byli Stanisław Siwiec i Michał Sołtysik - żołnierze AK. Czy liczba 14 więźniów figurująca w księgach więziennych jako liczba osób skazanych na karę śmierci odpowiada rzeczywistości? Na przestrzeni tylko listopada i grudnia 1944 roku odbyło się pięć masowych egzekucji, podczas których zamordowano 43 więźniów politycznych ${ }^{27}$. Nazwiska tych osób zapisane są w księgach więziennych Zamku Lubelskiego, ale w rubryce „powód przerwania aresztu” nie odnotowano wykonania wyroku śmierci, lecz ,ubył”. W zapisach powyższych ksiąg „ubył” występuje przy nazwiskach 65 osób, spośród których 28 stało się ofiarami egzekucji w 1945 roku, w większości wykonanych w marcu. Obok danych osobowych 169 żołnierzy AK widnieje zapis ,zwolniony”. Trzeba jednak zaznaczyć, że termin ten nie był równoznaczny z odzyskaniem wolności, wręcz przeciwnie, oznaczał wyrok śmierci. Tak było z czterema żołnierzami AK, których 18 października wywieziono w nieznane miejsce i rozstrzelano. Zapis ,zwolniony” widnieje nie tylko przy nazwiskach żołnierzy AK, lecz także przy nazwiskach 18 osób skazanych za „zbrodnie stanu”. Zacieranie zbrodni NKWD polegało też na tym, że nie wpisywano w księdze więziennej żadnych informacji o dalszych losach skazanych. Przykładem może być proces ,grupy Jemioły”, czyli grupy Czesława Rosińskiego. Rozstrzelano wówczas 11 osób bez żadnej adnotacji w księdze. W tych okolicznościach podanie liczby więźniów Zamku Lubelskiego, na których wykonano wyroki śmierci, może być tylko szacunkowe. W księgach zbrodnie na żołnierzach odnotowane są tylko w 14 przypadkach, natomiast większość zamordowanych to osoby „zwolnione”, „ubyłe” lub nieodnotowane.

„Księgi więzienne Zamku Lubelskiego z drugiej połowy 1944 roku” nie były dotąd przedmiotem krytycznego opracowania. Niniejszy artykuł stanowi pierwszą próbę przyjrzenia się dwóm pierwszym księgom pod kątem wykorzystania ich jako źródła historycznego.

${ }^{26}$ Z. Kowalski, J. A. Sil, Więzienie na Zamku Lubelskim, s. 24; S. Zwoliński, Skazani na śmierć przez sądy WP w latach 1944-1945, „Wojskowy Przegląd Historyczny”, t. 37, nr 1, 1992, s. 219-251; Straceni w polskich więzieniach 1944-1956, red. H. Pająk, Lublin 1994, s. 11.

${ }^{27}$ M. Kidasiński, Raport o zabijaniu. Zbrodnie sądów wojskowych na Zamku Lubelskim, Lublin 1997, s. 9. 
W dwudziestu rubrykach tego źródła jedynie dziesięć było wypełnionych w ponad $60 \%$, pozostałe zostały wypełnione najwyżej w $50 \%$. Dane osobowe aresztantów, jeżeli nie były świadomie zniekształcone przez nich samych lub kancelistę, mogą stanowić materiał źródłowy do ustalenia: wieku, przynależności narodowej i wyznaniowej, pochodzenia terytorialnego oraz roli społeczno-zawodowej, jaką osoby te pełniły. Natomiast rubryki dotyczące podstaw prawnych oskarżenia i wyroku, wypełniane przez odpowiednie organa władzy, są w większości niewypełnione. Świadczy to o świadomym przemilczaniu zbrodniczej działalności Sowietów, sądów wojskowych, Urzędu Bezpieczeństwa i Milicji Obywatelskiej. Kancelista wykonywał jedynie polecenia o nierejestrowaniu zbrodni, a rejestrując zacierał ślady zbrodni. Więźniów poddanych egzekucji zapisywał jako: „Zwolniony”, „ubył”, „przeniesiony”. Na podstawie zapisów dotyczących podstaw prawnych oskarżenia i wyroków nie można odtworzyć pierwszych miesięcy działalności władz komunistycznych na terenie Lubelszczyzny. Dane te nie są kompletne, brak zapisów w rubrykach dotyczących aktów oskarżenia, spreparowane protokoły zeznań, fałszywe materiały dowodowe i wyroki wydawane w tzw. sprawach kiblowych dowodzą przestępczej działalności organów ścigania i sądownictwa komunistycznego w roku 1944.

Na podstawie ksiąg więziennych Zamku Lubelskiego możemy niezaprzeczalnie stwierdzić, że $80 \%$ aresztowanych stanowili więźniowie polityczni, żołnierze AK, NSZ, BCh, cywilni działacze związani z rządem londyńskim oraz inteligencja ziemiańska. Osoby te były skazywane na śmierć, deportacje i wieloletnie więzienia. Patriotów walczących o wolność i suwerenność Polski nazywano: „reakcyjnym podziemiem”, „bandytami” lub „współpracownikami Hitlera”. 